Marquette University

e-Publications@Marquette

College of Communication Faculty Research and

Publications

Communication, College of

$1-1-2012$

Intercultural New Media Studies: The Next Frontier in intercultural Communication

Robert Shuter

Marquette University, robert.shuter@marquette.edu

Accepted version. Journal of Intercultural Communication Research, Vol. 41, No. 3 (2012): 219-237.

DOI. (C) 2012 Taylor \& Francis. Used with permission. 


\title{
Intercultural New Media Studies: The Next Frontier in Intercultural Communication
}

\author{
Robert Shuter \\ Diederich College of Communication, Marquette University \\ Milwaukee, WI
}

\begin{abstract}
New media (ICT's) are transforming communication across cultures. Despite this revolution in cross cultural contact, researchers in communication and the social sciences have largely ignored the impact of new media on intercultural communication. This groundbreaking article defines the parameters of a new field of inquiry called Intercultural New Media Studies (INMS) which explores the intersection between ICT's and intercultural communication. Composed of two research areas - (1) new media and intercultural communication theory and (2) culture and new media - INMS investigates new digital theories of intercultural contact as well as refines and expands 20th century intercultural communication theories, exploring their salience in a digital world. Intercultural new media studies promises to increase our understanding of intercultural communication in a new media age and is the next frontier in intercultural communication.
\end{abstract}

New media (ICT's) are transforming communication across cultures. The internet (CMC), social network sites (SNSs), mobile phones, Skype, text messaging, on-line games (MMOGs), virtual worlds, and blogs have dramatically increased contact between individuals and groups from different cultures. No longer restricted

[Citation: Journal/Monograph Title, Vol. XX, No. X (yyyy): pg. XX-XX. DOI. This article is @ [Publisher's Name] and permission has been granted for this version to appear in e-Publications@Marquette. [Publisher] does not grant permission for this article to be further copied/distributed or hosted elsewhere without the express permission from [Publisher].] 
primarily to face-to-face encounters, people worldwide utilize ICT's to communicate instantaneously with others regardless of geo-political boundaries, time, or space.

Despite this revolution in cross cultural contact, communication researchers have largely ignored the impact of new media on intercultural communication and, instead, concentrated their limited scholarship on how new media is utilized in different cultures (Barker \& Ota, 2011; Baron \& Af Segerstad, 2010; Koc, 2006), in what ways culture affects new media development and design (Campbell,2007; De Goede, Van Vianen, \& Klehe, 2011), and how computer mediated communication (CMC) is influenced by culture (Guéguen, 2008; Chen, 2012; Mollov, \& Schwartz, 2010). What's missing from communication journals -- except for Shuter's (2011) guest edited forum on intercultural new media research -- are lines of research on how ICT's affect intercultural communication between individuals and groups. Research on this topic could challenge more than 50 years of intercultural communication knowledge and theory rooted in 20th century paradigm of face to face interaction. This essay aims to accomplish two goals: (1) propose a new field of study called Intercultural New Media Studies (INMS) which explores the intersection between ICT's and intercultural communication, and (2) introduce and situate the articles in this special issue within intercultural new media studies.

\section{Intercultural New Media Studies (INMS): Parameters of a Field}

The primary focus of this field of study is how ICT's impact communication between people who do not share the same cultural backgrounds, often defined as national culture (nation state) and coculture (i.e. ethnicity and race) in early intercultural communication research, but expanded contemporarily to include myriad cultures, both within and across geo-political boundaries, as well as hybridized cultures that have developed transnationally due to migration, diaspora, and time and space reconfigurations in a digital age (Clothier, 2005; Dooly, 2011; McEwan \& Sobre-Denton 2011; Steinkuehler \& Williams, 2006). Of secondary interest, but still considerably important, is the relationship between culture and new 
media; namely, how does culture impact the social uses of new media within and across societies, and in what ways do new media affect culture? There is scant research on the primary area and significantly more data on the secondary area.

The primary area of inquiry may alter our understanding of the process of intercultural communication by identifying new digital theories of intercultural contact as well as refining and expanding extant intercultural communication theories pertaining to such areas as acculturation/adaptation, third culture development, intercultural competence, high context/low context communication, co-cultural communication, cultural identity, intercultural dialogue, culture shock/stress, stereotyping, ethnocentrism, racism, intercultural awareness, intercultural conflict, speech codes, and intercultural relationship development. Although there is limited data on the impact of new media on many of these intercultural areas, the available research suggests that new media play a major role in the ebb and flow of intercultural encounters, conceivably augmenting 20th century theories on communication across cultures

\section{New Media and Intercultural Communication Theory}

This section explores the possible effects of new media, and raises important 21st century questions, on five seminal areas of intercultural communication and their attendant theories: cultural identity, intercultural dialogue, third culture, acculturation, and intercultural competence.

\section{Cultural Identity}

Cultural identity, according to social identity theory, is derived from membership in social groups, a legacy of in-group identification that also influences communication in social groups (Tajfel \& Turner, 1986). It is co-created and negotiated, according to Collier (2002), impacted by internal and external factors that she calls avowal and ascription, and also affected by communication. This view of cultural identity is rooted in 20th century assumptions about the origins of the self in relationship to others; that is, social identity is based on group contact(s) that is fixed in space and time, producing discernable social

[Citation: Journal/Monograph Title, Vol. XX, No. X (yyyy): pg. XX-XX. DOI. This article is @ [Publisher's Name] and permission has been granted for this version to appear in e-Publications@ Marquette. [Publisher] does not grant permission for this article to be further copied/distributed or hosted elsewhere without the express permission from [Publisher].] 
identity (ies) that varies in salience depending on the social context(s). However, in a new media era of perpetual contact (Katz \& Arkus, 2002), where individuals live in virtual spaces with myriad others, is this perspective relevant and sufficient for explaining the development and maintenance of cultural identity in the 21 st century?

Singh (2010) argues that with the advent of the internet, individuals are inducted into "virtual cultures," technological, homogenized entities not grounded in time or space. Beniger (1987) refers to these virtual cultures as pseudo-communities as opposed to traditional organic communities, which are bound by physical space and rely on face-to-face communication. These virtual cultures can alter pre-existing cultural identities, according to Singh, threatening traditional indigenous identifications that are co-created, negotiated, and developed in concert with social identity theory.

Chen and Dai (2012) maintain that virtual communities challenge pre-existing cultural identities because of asymmetrical power relationships that are inherent in these communities. They argue that since Western culture has an implicit power advantage even in cyberspace, virtual communities are not culture neutral and, hence, may shape the development of new cultural identities, which may not turn out to be hybrid constructs.

A hybridized cultural identity, according to Clothier (2005), can emerge from being inducted into a virtual community composed of diverse people and cultural influences that border and overlap each other, which Clothier calls a hybrid virtual culture. Theoretically, hybrid virtual cultures and their attendant hybrid identities are antagonistic to authority and cultural hegemony, according to Clothier. However, because the West dominates cyberspace in so many significant ways (Chen \& Dai, 2012) - linguistically through the English language, symbolically via the West's pervasive icons, and materially in Western created hardware and software -- it is unclear whether hybrid cultural identities are, indeed, possible, and whether identity co-creation and negotiation can truly occur in virtual communities consisting of disparate, unrelated individuals. 
NOT THE PUBLISHED VERSION; this is the author's final, peer-reviewed manuscript. The published version may be accessed by following the link in the citation at the bottom of the page.

It does appear, however, that when virtual communities are composed of culturally homogenous members - in-group members that may or may not know one another - these communities can support and reinforce pre-existing cultural identities. Hopkins (2008) found that young Australian Muslim Turks, who felt marginalized by Australian anti-Islamic feeling, successfully utilized new media to connect with Muslims worldwide, reinforcing their identities and faith. Croucher and Cronn-Mills (2011) discovered that French-Muslim used social networking sites to maintain their Muslim identities, sometimes at the expense of their French identities. Oh (2012) reports that second generation Korean American adolescents use transnational Korean media to enhance intra-ethnic bonds and support their Korean identities. In fact, organic communities in diaspora appear to successfully utilize social media and other new media to retain and reinforce their cultural identities (Croucher, 2011).

There is also evidence that ethnic and racial groups in the United States utilize social media to present their cultural identities in highly elaborate ways. Grasmuck, Martin, and Shanyang (2009) found that African Americans, Latinos, Native Americans, and Vietnamese construct Facebook profiles and narratives that proudly and explicitly proclaim their cultural roots. Their self presentations not only reinforce cultural identities but appear to be tacit opposition, according to the authors, to social dynamics in the larger society that promote a color blind ideology. Hence, unlike early internet research suggesting that cyberspace is culturally and racially neutral (Turkle, 1995) - a virtual utopia where cultural identity and status differences are minimized this study and others suggest that ethno-racial identity presentations in nonymous SNS's empower minority and marginalized users ( $\mathrm{Hu} \&$ Leung, 2003; Mehra, Merkel \& Bishop, 2004).

Available literature on cultural identity and new media raise several important suppositions regarding the salience of past cultural identity research conducted in organic, face-to-face communities.

1. It is not clear how cultural identities are constructed in virtual communities. Cultural identities may not necessarily be cocreated or negotiated in virtual communities according to the literature reviewed here. Negotiation and co-creation require

[Citation: Journal/Monograph Title, Vol. XX, No. X (yyyy): pg. XX-XX. DOI. This article is @ [Publisher's Name] and permission has been granted for this version to appear in e-Publications@Marquette. [Publisher] does not grant permission for this article to be further copied/distributed or hosted elsewhere without the express permission from [Publisher].] 
some degree of parity between parties, which may not be possible in virtual communities since information technology hardware, software, web design, and new/social media - appear to privilege the West. Moreover, since virtual communities are often pseudo-communities -- sometimes anonymous and generally disconnected from physical space and time -- intimacy and engagement can be quite limited, which are requisites for co-creation and negotiation.

2. It is not clear how virtual and organic communities create hybrid cultural identities. While the literature suggests that hybrid cultural identities can emerge in either organic or virtual communities, it is unclear how this process unfolds. If cocreated and negotiated, how is hybridity created in virtual and organic communities when traditions, symbols, and icons are co-opted by dominant and powerful cultural forces? Similarly, how is hybridity realized in cyberspace when race, ethnicity and culture are so pervasive? 
NOT THE PUBLISHED VERSION; this is the author's final, peer-reviewed manuscript. The published version may be accessed by following the link in the citation at the bottom of the page.

3. The dynamics of maintaining cultural identity may be different in virtual communities than organic ones. The literature suggests that co-cultures and marginalized individuals may find more and different opportunities for presenting and reinforcing their cultural identities in virtual communities than organic ones. Cyberspace can empower disenfranchised groups in unique and powerful ways that are differentiated from the dynamics of faceto-face interaction. What are the dynamics of identity preservation in virtual communities and how do they differ from organic communities?

\section{Intercultural Dialogue and Third Culture}

Intercultural dialogue is an important goal of intercultural contact and, as such, has been widely examined. It is generally considered an ideal type of contact, requiring openness and empathy, and resulting in a deep understanding of other (Ganash \& Holmes, 2011). Unlike casual contact, intercultural dialogue, according to the literature, requires communicators to be aware of, even challenge, their personal values and predispositions - albeit, any aspect of their background - that may prevent a deep understanding of others. Similarly, to achieve intercultural dialogue, communicators must be open to accepting differences -- a deeply rooted principle of dialogue founded on the work of Buber (1965), Gadamer (1989), and Habermas (1987), 20th century theorists who wrote about dialogue in organic communities. In fact, since theories, models and strategies for achieving intercultural dialogue emerge from a 20th century face-toface paradigm, it is unclear whether dialogue literature - or dialogue itself -- are applicable to the virtual world.

Literature on virtual intercultural dialogue is limited, but the evidence suggests that it is challenged by many of the same factors that affect dialogue in organic communities. Hichang and Jae-Shin (2008) examined computer mediated groups composed of students from the United States and Singapore and discovered that virtual intercultural collaboration was constrained by preexisting social networks and intergroup boundaries formulated in their respective countries and cultures. They found that the students' willingness to collaborate and share information with others were affected by 
whether their virtual partners were member of their in-groups and shared their cultural values. Similarly, Pfeil, Zaphiris, and Ang (2006) hypothesized correctly that cultural values influence collaboration, discovering that collaborative authoring patterns of Wikipedia reflected predominant cultural values of French, German, Japanese, and Dutch authors. Utilizing Hofstede's values scheme, this study identified unique cultural styles of collaboration that correlated with individualism and collectivism, power distance, and femininity and masculinity. The researchers concluded that cultural differences found in the physical world are also in play in virtual communities.

Although virtual collaboration may lead to intercultural dialogue, and perhaps is a precursor to dialogue, collaboration is frequently missing requisite dialogic elements like empathy and deep understanding. Hence, the question remains: Is intercultural dialogue possible in the virtual world? Studies of third culture in cyberspace offer some additional insight into this question.

The concept of third culture was originally developed by Fred Casmir $(1978,1989,1997)$ who posited that individuals from different cultures can optimize their relationship in a third culture which he described as the "..conjoining of their separate cultures" into a more inclusive culture ".. that is not merely the result of a fusion of two or more separate entities, but the also the product of the harmonization of composite parts into a coherent whole." (1989, p. 294.). Dialogue is necessary to develop a third culture, according to Casmir, which he argues cannot be achieved without empathy and deep understanding of others. Starosta and Olorunnisola (1998) add that individuals must be consciously aware of their differences and capable of suspending judgment to build a third culture, a product of convergence, integration, and mutual assimilation Once achieved, third culture provides an ideal climate to interact because it is mutually accepting, supportive, and cooperative.

Although third cultures are difficult to create in the physical world, some research suggests that they may be more achievable in virtual communities. McEwan and Sobre-Denton (2011) argue that the ease of technological access to cultural others combined with reduced social and economic costs significantly increase the probability of 
developing third cultures in the virtual world. Virtual communities, unlike organic ones, do not require leaving ones domicile to be an active member nor are they plagued by face threats due to social errors, according to the authors. In fact, new media provides users with technological tools to manage social distance which McEwan and Sobre-Denton suggest increase cultural risk taking and experimentation, leading more readily to virtual third cultures.

There is also evidence, however, that third cultures are difficult to construct in the virtual world. Nelson and Temples (2011) examined graduate students' attempts to negotiate memberships in multiple online communities during an international exchange program. The students experienced numerous cultural issues in constructing on-line relationships in international virtual communities, leading the authors to conclude that the process of what they called "reconciliation," which is comparable to third culture building, is complex and sometimes impossible in cyberspace. Interestingly, Steinkuenier and Williams (2006) discovered that while on-line games provide what they refer to as a "third space" for participants - a virtual dimension where people can socialize informally - these spaces are generally useful for bridging social capital and do not usually provide deep emotional support.

While data are inconclusive on whether intercultural dialogue or third culture can actually occur in virtual communities, the research does suggest that the use of multiple new media technologies in a virtual community may increase the emotional attachment of participants and, hence, the prospect for dialogue. Wang (2012) found that Facebook is a viable platform for building cross-cultural friendships among Taiwanese and American university students; however, to retain these friendships after the completion of a project, other Web 2.0 applications are necessary. Dooly (2011) also discovered that the effectiveness and depth of on-line cross-cultural relationships between two groups of student teachers in Spain and the US were affected by the number and nature of communication platforms utilized, including Skype, Moodle, Voicethread and Second Life. Finally, Develotte and Leeds-Hurwitz (in-press) successfully facilitated intercultural dialogue between French and US students utilizing desktop video conferencing, including both video and chat. 
NOT THE PUBLISHED VERSION; this is the author's final, peer-reviewed manuscript. The published version may be accessed by following the link in the citation at the bottom of the page.

They have also used MSN Messenger, Skype, and Adobe Connect to achieve similar results.

In summary, the following suppositions emerge about intercultural dialogue and third culture building from intercultural new media literature.

1. Intercultural dialogue and third culture building, as defined in face-to-face literature, may be difficult to achieve in virtual communities. The on-line literature examined in this section suggests that empathy and deep understanding - prerequisites for dialogue and third culture building - may not be readily achievable in the virtual world.

2. Intercultural dialogue and third culture building may be governed by different processes in virtual communities than organic ones. The reviewed research suggests that factors like anonymity and controlling social distance,, which are inimical to face-to-face dialogue and third culture building, may help produce both outcomes in the virtual world.

3. It may be necessary to utilize multiple new media platforms to achieve intercultural dialogue and third culture in a virtual world. Research suggests that a mix of new media platforms, including on-line and video chat/conferencing, may increase the chances for achieving intercultural dialogue and third culture in virtual communities.

4. External factors from the physical world that affect intercultural dialogue and third culture building may also impinge on both outcomes in the virtual world. Social factors from the physical world, including stereotyping, predispositions, and different cultural values, may affect the development of intercultural dialogue and third culture in the virtual world.

\section{Acculturation and Intercultural Competence}

Communication research abounds on how people adapt to new cultures, and much of the data examine the impact of interpersonal interaction and mass media on acculturation. Young $\operatorname{Kim}(1988,2001)$, the leading communication scholar on acculturation, provides an integrative model to explain how sojourners' background and 
personality, as well as the quality and quantity of their interpersonal encounters, influence cultural adaptation. Kim found that positive social communication in the host culture, combined with reasonable and successful ethnic support, provide cultural knowledge and skills and emotional stability to acculturate successfully. She also integrates mass media into her model, arguing that acculturation is influenced by the nature, type, and frequency of media consumption patterns. Additional researchers have also have found that host culture social communication and mass media play a significant role in acculturation as do ethnic social support and media from a sojourner's culture of origin (Durham, 2004; Khan, 1992; Raman \& Harwood, 2008). Although there is a good deal of research on the effects of social communication and mass media on acculturation, there is scant data on new media and acculturation.

Available new media studies suggest that the internet and selected on-line communities facilitate the process of acculturation. For example, Ye (2005) found that Chinese international students who utilize on-line ethnic support groups composed of Chinese students experience significantly less acculturative stress and more emotional support. Ye's finding confirms Ying and Liese's (1991) early investigation that while on-line ethnic support groups provide important emotional support, they do not help significantly with learning skills necessary to be successful in a new culture.

Jiali (2006) examined traditional and on-line support networks among Chinese international students and discovered that students who received support from both on-line ethnic groups and interpersonal networks in the host culture tended to experience fewer social difficulties in acculturation. Further, Chinese international students who sustained their on-line interpersonal networks in their home country had fewer mood disturbances during the adaptation process. According to Jiali (2006), Chinese who newly arrived to a culture tended to report higher support levels from on-line ethnic groups than those who had been living in the culture for a longer time period. Confirming and extending Jiali's (2006) findings, Chen (2010) found that the longer immigrants lived in a host culture, the less likely they surfed home country websites and the more apt they were to 
communicate on-line with residents of the host culture, which facilitates their acculturation.

Surprisingly, there is very limited data on the influence of social networking sites on acculturation. Croucher and Cronn-Mills (2011) found that the use of social networking sites among French Muslims reinforced their Islamic identities rather than their French identities, which complicated the adaptation process. In a conceptual essay, Croucher (2011) hypothesized that increased use of social networking sites composed of people from the same culture may serve as an obstacle to acculturation. Utilizing cultivation and ethnic group vitality theories, Croucher argued that increased exposure to homogenous social networking sites tend to increase in-group identification and negatively affect cultural adaptation. Croucher's research on social networking sites contrasts with studies reviewed here on the positive effects of on-line ethnic support networks on acculturation. Perhaps, social networking sites provide a unique portal for ethnic networking that distinguish them from other types of on-line ethnic encounters.

Not only is acculturation affected by face-to-face and on-line support networks, but it is also influenced by the individual's level of intercultural competence, often measured by awareness of and openness to cultural differences as well as the abilities and skills necessary to successfully navigate a new culture (Wiseman \& Koester, 1993). While Kim (2001) and others have found that individuals learn about new cultures incrementally, largely through pre-departure preparation, social communication in the host culture, and mass media, there is also evidence that on-line encounters can increase intercultural competence and enhance acculturation potential.

Studies on internet mediated second language learning suggest that on-line international exchanges accelerate language acquisition and intercultural competence. Chun (2011) found that on-line contact between Germans and American university students learning one another languages significantly increased their cultural awareness and intercultural communication skills. Belz (2005) reported that internet mediated language learning between Germans and Americans dramatically improved the participants' ability to use questions to ascertain cultural information, which they argue is an essential 
component of intercultural competence. While investigating the effect of blogs on second language learning for Spanish and American students, Elola and Oskoz (2008) discovered that blogging in newly acquired languages improved both groups' intercultural competence.

Despite the popularity of virtual gaming worlds like Second Life, World of War Craft, EverQuest, Final Fantasy, and Xbox Live, there is very limited data on whether virtual worlds affect intercultural competence and, hence, acculturation potential. In an important study, Diehl and Prins (2008) explored the cross-cultural exchanges of Second Life participants, evaluating both their real and virtual world interactions. They found that SL enhanced the participants' "intercultural literacy" by promoting intercultural friendships, second language acquisition, and openness to diverse cultures, practices, and attitudes. In a related study, Ward (2010) found that the acculturation strategies utilized in the physical world are also employed when participants' culturally adapt to virtual gaming worlds, which suggest that this type of cyber-experience may enhance skills that increase acculturation potential.

The data on new media and acculturation raise many provocative suppositions about role of new media in acculturation and intercultural competence.

1. Computer mediated communication (CMC) appears to play a positive role in acculturation and intercultural competence. Available data suggest that on-line exchanges between members of ethnic groups provide important emotional support and generally play a positive role in acculturation. In contrast, on-line cross-cultural exchanges during training sessions for second language acquisition can increase intercultural competence, which can increase acculturation potential.

2. Virtual gaming worlds may play a useful role in improving acculturation potential and increasing intercultural competence. Limited data suggest that participating in Second Life may improve intercultural skills that are essential for intercultural competence and successful cultural adaptation. Data also suggest that participants of virtual gaming worlds may utilize 
many of the same acculturation strategies that are used in the physical world.

3. Social media appear to affect acculturation and intercultural competence, but the data are too limited to speculate on the types of effects. Social media (SNS) - including Facebook, Twitter, and My Space as well as culturally indigenous brands like QQ (China), Orkut (India) and Weibo (China) -- have been virtually unexamined in terms of their effects on acculturation and intercultural competence. Limited data suggest that ethnic social media may negatively affect acculturation, but it is unclear how cross-cultural uses of SNSs affect acculturation and intercultural competence. Do social networking sites increase intercultural contact and, hence, improve acculturation potential or do they merely enable users to communicate with in-groups who share their cultural backgrounds and limit acculturation? (Shuter, 2011).

4. The interplay between new media, mass media, and acculturation is unexplored and requires careful analysis. Given the interactive and personal nature of new media, could they have more impact on acculturation and intercultural competence than traditional mass media?

Does frequency of new media use impact the potential effects of mass media on acculturation and intercultural competence?

5. The effects of mobile devices on acculturation and intercultural competence has not been explored, and given their omnipresence in the 21st Century, this new media platform warrants examination. Mobile phones, smart phones, and i-Pads are ubiquitous and powerful. Cell phones are more plentiful worldwide than are internet connections, and more people text message and mobile call than engage in computer mediated communication (Shuter and Chattopadhayay, 2010; Shuter, 2012). Yet, there is no published research on text messaging (SMS), mobile calling - albeit, any application of a mobile device - and acculturation and intercultural competence.

6. Since new media are not included in acculturation theories developed in the 20th century, these theories may not adequately explain how people acculturate in the 21st century. 
It's important to revisit and reconfigure major theories of acculturation to ensure that they sufficiently include new media. In addition, how individuals acculturate in on-line communities and virtual worlds may provide new insights into the process of acculturation in the physical world.

This section of the paper explored the possible effects of new media on five major areas of intercultural communication; however, it is not an exhaustive analysis. There are scattered new media studies on other important areas of intercultural communication including stereotyping (Chia-I, 2008; Guéguen, 2008; Nakamura, 2009), high context/low context communication (Pflug, 2011; Richardson \& Smith, 2007; Würtz, 2005), culture shock/stress (Karlsson, 2006; Martinez, 2010), intercultural relationship development(Tokunaga, 2009; Youngok \& Hara, 2005), and intercultural conflict (Mollov \& Schwartz, 2010; St.Amant, 2002). New media data in these areas are too limited to draw any conclusions except that there is much research to be done to determine whether 20th century intercultural communication theories adequately explain our current intercultural transactions. The essay turns now to the impact of culture on the social uses of new media, the secondary research area in intercultural new media studies.

\section{Culture and New Media: Secondary Area of Intercultural New Media Studies}

Culture and new media are conjoined. Not only does culture affect the social uses of new media, but new media appears to change culture. Both areas are important dimensions of intercultural new media studies and, unlike the previous section on new media and intercultural communication theory, there has been more research conducted here. In addition, there has been growing research interest on the effects of new media on cultural traditions and communication patterns in societies across the globe.

Early research on culture and new media focused on computer mediated communication (CMC) and explored such topics as intercultural communication and CMC (Ma, 1996), country differences in CMC (Yoon, 1996), CMC and the rise of electronic global culture (Ess, 2001; Jones, 2001), and the utilization of CMC in student 
exchange programs and multicultural classrooms (Meagher and Castanos, 1996; Colomb and Simutis (1996). More recently, scholars have examined the impact of culture on the social uses of additional new media platforms including mobile phones (Baron \& Af Segerstad, 2010; Campbell, 2007; Schroeder, 2010), text messaging ( Ling, 2008; Shuter \& Chattapadhyay,2010; Spurgeon \& Goggin, 2007), social media (Barker \& Ota, 2011; Lin, Peng, M. Kim, S. Kim \& LaRose, 2012; Shu-chuan \& Sejung Marina, 2011), blogs (Elola \& Oskoz, 2008; Karlsson, 2006), virtual worlds (Diehl \& Prins, 2008; Green \& Singleton, 2007; Wang, Walther, \& Hancock, 2009), and multiplayer on line games (Chia-I, 2008; Nakamura, 2009; Steinkuehler \& Williams, 2006; Ward, 2010).

As new media studies have grown exponentially in the 21st century so, too, has research increased on country variations in the social uses of new media, the focal point of most cross-cultural new media investigations. In fact, after an exhaustive analysis of all published studies from 2005-2011 in New Media and Society (NMS) and the Journal of Computer Mediated Communication (JCMC) -arguably, the two major communication journals on new media - it was found that both journals published 293 international new media studies, and just forty one of these included more than one country in the investigation. Since eighty six percent (252) are single country studies, they are overwhelming intracultural not intercultural examinations of the social uses of new media.

While there are myriad journals that publish new media research, JCMC and NMS are excellent indicators of communication research trends on culture and new media. A close analysis of 293 international new media articles in both journals reveal the following trends for (1) the frequency of research on major platforms and (2) percentage of studies aimed at theory validation, either mass media or new media theories.

(1) Most of the international articles (195:66\%) are single culture investigations of computer mediated communication (i.e. on-line exchanges, websites, internet, instant messaging). (2) Mobile phone research (calling and text messaging) conducted internationally is the next most frequently researched platform ( 
$43: 15 \%)$, followed by social networking sites (17:6\%), multiplayer online games $(15: 5 \%)$, blogging $(13: 4 \%)$, and, finally, a few scattered studies on email and You Tube, with zero international articles on virtual worlds.

(3) The overwhelming majority of international new media investigations (240:82\%) are theory validation studies that primarily attempt to refine new media or mass media theories, with limited analysis of socio-cultural implications of new media.

Interestingly, platform research trends identified in JCMC and NMS are also supported by international studies on text messaging (Shuter and Chattopadhyay, 2010; Shuter, 2012) and mobile phones (Shuter and Chattopadhyay, 2012). Recently, communication scholars have also confirmed research trend three -- the limited availability of socio-cultural critiques of new media, society, and intercultural communication (Cheong, Martin, MacFadyen, 2012).

Given the research trends on culture and new media, there are many avenues for future investigations to optimize its' inclusion in intercultural new media studies. Conceptually, there needs to be significantly more emphasis on intercultural new media research that takes a socio-cultural perspective. This translates into new media studies that explore topics such as indigenous (i.e. country, co-culture, hybridity) cultural patterns of new media use, critical analyses of new media and society, and the impact of culture on the social uses of new media. A socio-cultural perspective should also produce studies that develop, refine or extend cultural theories of new media communication including, but not limited to, cultural values and the social uses of new media, co-cultural theory and new media behavior, and socio-cultural factors and cultural preferences of new media platforms. The studies contained in this special issue include multiple examples of new media research grounded in a socio-cultural perspective.

Hasler and Friedman's exploration of avatar use in a virtual world, Lee and Taniguichi's study of fat talk on Facebook, and Smith and Cooley's investigation of face-ism on Facebook are incisive examples of research that explore socio-cultural influences on social uses of new media. Hasler and Friedman found that Asian avatar 
dyads in a virtual world interact at larger distances than European avatar dyads which, they report, is consistent with socio-cultural expectations in the physical world. Lee and Taniguichi argue that values differences between American and Japanese cultures contribute to the participants' significantly different reactions to Facebook posts about personal appearance. And Smith and Cooley report that while men generally display more facial prominence (face-ism) than women in personal photos posted on Facebook, national culture also plays a prominent role in face-ism on SNSs, with some countries displaying more face-ism gaps between genders than others. In different but important ways, these studies enhance understanding of the tight relationship between the cultures of the physical and virtual worlds, demonstrating how crucial it is to consider and identify socio-cultural factors when analyzing the social uses of new media.

The social uses of new media are also influenced by global socio-cultural factors unrelated to any specific country, according to studies by Waters and Lo on cross-cultural organizational differences on Facebook, and Ling, Canright, Bjelland, Enge-Monsen, and Sundsoy on core mobile phone social networks. Waters and Lo report that organizational uses of SNSs are only minimally affected by traditional cultural values, concluding that global, virtual cultures may be developing. Ling et al found, unexpectedly, that core mobile phone social networks are not different in developed and developing countries, indicating that global socio-cultural factors, unrelated to world region or co-culture, may be driving social uses of mobile phones.

Based on the preceding research trends, it's also important to conduct significantly more intercultural new media investigations that include two or more cultures and examine a broader range of new media platforms. While single country investigations are important because they reveal intracultural patterns of new media use, multiple culture investigations are also essential for generating comparative cultural data on the social uses of new media. In addition to continuing intercultural research on computer mediated communication, it is important to examine, with much greater frequency, the social uses of additional new media platforms across cultures, particularly mobile phones, text messaging, social networking sites, multiplayer on-line permission has been granted for this version to appear in e-Publications@Marquette. [Publisher] does not grant permission for this article to be further copied/distributed or hosted elsewhere without the express permission from [Publisher].] 
games, and virtual worlds. With an abundance of intercultural data on these and other platforms, researchers will have a better understanding of the socio-cultural dynamics that drive the social uses of new media.

Lastly, future studies on culture and new media should focus more on generating intercultural theories on the social uses of new media. The current trend of conducting mass media or new media theory validation studies is no substitute for formulating and refining culture based new media theories that detail and explain socio-cultural influences on the social uses of new media. There are a few culture based new media theories, including Cheong, Martin, and MacFadyen's (2012) critical new media theory and Shuter and Chattopadhyay's (2012) socio-cultural values theory of mobile phone activity. Both theories address the inextricable relationship between socio-cultural forces and new media, with Cheong et al focusing on power and new media, and Shuter and Chattopadhyay exploring cultural values and mobile phone activity.

\section{Conclusion}

This essay conceptualizes the parameters of a new field of inquiry called intercultural new media studies, which consists of two areas: (1) new media and intercultural communication theory and (2) culture and new media. Exploring the intersection of new media and intercultural communication theory has the potential to refine and expand 20th century theories of intercultural communication grounded in a face-to-face paradigm. In light of current intercultural new media studies, five major intercultural communication theories (ICC) critiqued in this essay need to be reexamined and reconfigured, resulting in new or modified ICC theories more applicable to a digital era. Area two, culture and new media, focuses on the interdependent relationship between culture and new media, a fertile topic of inquiry delineating the influence of socio-cultural forces on the social uses of new media within and across cultures. Intercultural new media studies promises to expand our understanding of intercultural communication in a new media age and is, truly, the next frontier in intercultural communication.

[Citation: Journal/Monograph Title, Vol. XX, No. X (yyyy): pg. XX-XX. DOI. This article is @ [Publisher's Name] and permission has been granted for this version to appear in e-Publications@ Marquette. [Publisher] does not grant permission for this article to be further copied/distributed or hosted elsewhere without the express permission from [Publisher].] 
NOT THE PUBLISHED VERSION; this is the author's final, peer-reviewed manuscript. The published version may be accessed by following the link in the citation at the bottom of the page.

\section{References}

Barker, V., \& Ota, H. (2011). Mixi Diary versus Facebook Photos: Social networking site use among Japanese and Caucasian American females. Journal of Intercultural Communication Research, 40 (1), 39-63. doi:10.1080/17475759.2011.558321

Baron, N. S., \& Af Segerstad, Y. (2010). Cross-cultural patterns in mobilephone use: Public space and reachability in Sweden, the USA and Japan. New Media \& Society, 12 (1), 13-34. doi: $10.1177 / 1461444809355111$

Belz, J. A. (2005). Intercultural questioning, discovery and tension in Internet-mediated language learning partnerships. Language \& Intercultural Communication, 5 (1), 3-39.

Beniger. J. (1987). Personalization of mass media and the growth of pseudocommunity. Communication Research, 14 (3), 352-371.

Buber, M. (1965). The knowledge of man. New York, NY: Harper \& Row.

Casmir, F.L. (1978). Intercultural and international communication. Washington, DC: University Press of America.

Casmir, F.L. (1997). Ethics in intercultural and international communication. Mahwah, NJ: Lawrence Erlbaum.

Camir. F.L., \& Asuncion-Lande, N. (1989). Intercultural communication revisited: Conceptualization, paradigm building, and methodological approaches. In J.A. Anderson (Ed.), Communication Yearbook 12 (pp. 278-309). Newbury Park: Sage.

Campbell, S. W. (2007). A cross-cultural comparison of perceptions and uses of mobile telephony. New Media \& Society, 9 (2), 343-363. doi: $10.1177 / 1461444807075016$

Chen, G.M. (2012). The impact of new media on intercultural communication in global context. China Media Research, 8 (2), 1-10.

Chen, G.M., \& Dai, X-d. (2012). New media and asymmetry in cultural identity negotiation. In P. H. Cheong, J. N. Martin, \& L. Macfadyen, L. (Eds.), New media and intercultural communication: Identity, community and politics (pp. 123-138). New York: Peter Lang.

Chen, W. (2010). Internet-usage patterns of immigrants in the process of intercultural adaptation. Cyberpsychology, Behavior, and Social Networking, 13(4), 387-399.

Cheong, P. H., Martin . J. N., \&L. Macfadyen, L. (Eds.). (2012). New media and intercultural communication: Identity, community and politics. New York: Peter Lang.

Chia-I, H. (2008). A cross-cultural comparison of gender representation in massively multiplayer online role-playing games: A study of Taiwan and the United States. China Media Research, 4 (2), 13-25.

Chun, D. M. (2011). Developing intercultural communicative competence through online exchanges. CALICO Journal, 28 (2), 392-419.

[Citation: Journal/Monograph Title, Vol. XX, No. X (yyyy): pg. XX-XX. DOI. This article is @ [Publisher's Name] and permission has been granted for this version to appear in e-Publications@ Marquette. [Publisher] does not grant permission for this article to be further copied/distributed or hosted elsewhere without the express permission from [Publisher].] 
NOT THE PUBLISHED VERSION; this is the author's final, peer-reviewed manuscript. The published version may be

accessed by following the link in the citation at the bottom of the page.

Clothier, I. M. (2005). Created identities: Hybrid cultures and the internet. Convergence: The Journal of Research into New Media Technologies, 11 (4), 44-59. doi:10.1177//1354856505061053

Collier, M.J. (2002). Intercultural alliances: Critical transformation. California: Sage Publications.

Colomb, G., \& Simutis, J. (1996). Visible conversation and academic inquiry: $\mathrm{CMC}$ in a culturally diverse classroom. In S. C. Herring, (Ed.), Computer-mediated communication: Linguistic, social and crosscultural perspectives (pp. 203-224). Amsterdam: John Benjamins Publishing Company.

Croucher, S.M. (2011). Social networking and cultural adaptation: A theoretical model. Journal of International and Intercultural Communication, 4 (4), 259-264.

Croucher, S., \& Cronn-Mills, D. (2011). Religious misperceptions: The case of Muslims and Christians in France and Britain. New York: Hampton Press.

DeGoede, M. E., Van Vianen, A. M., \& Klehe, U. (2011). Attracting applicants on the web: PO fit, industry culture stereotypes, and website design. International Journal of Selection \& Assessment, 19 (1), 51-61. doi: $10.1111 / \mathrm{j} .1468-2389.2010 .00534 . x$

Develotte, C., \& Leeds-Hurwitz, W. (in press). Creating contexts for intercultural dialogue in the classroom. In N. Haydari, \& P. Holmes (Eds.), Studies in intercultural dialogue. Iowa: Kendall Hunt.

Dooly, M. (2011). Crossing the intercultural borders into 3rd space culture(s): Implications for teacher education in the twenty-first century. Language \& Intercultural Communication, 11 (4), 319-337. doi: $10.1080 / 14708477.2011 .599390$

Diehl, W. C., \& Prins, E. (2008). Unintended outcomes in second life: Intercultural literacy and cultural identity in a virtual world. Language \& Intercultural Communication, 8 (2), 101-118. doi: $10.1080 / 14708470802139619$

Durham, M.G. (2004). Constructing the "new ethnicities:"Media, sexuality, and diaspora identity in the lives of South Asian immigrant girls. Critical Studies in Media Communication, 21, 140-161.

Elola, I., \& Oskoz, A. (2008). Blogging: Fostering intercultural competence development in foreign language and study abroad contexts. Foreign Language Annals, 41 (3), 454-477.

Ess, C. (Ed.). (2001). Culture, technology, communication: Towards an intercultural global village. Albany, NY: State University of New York Press.

Gadamer, H. G. (1989). Truth and method. New York: Crossroads.

[Citation: Journal/Monograph Title, Vol. XX, No. X (yyyy): pg. XX-XX. DOI. This article is @ [Publisher's Name] and permission has been granted for this version to appear in e-Publications@Marquette. [Publisher] does not grant permission for this article to be further copied/distributed or hosted elsewhere without the express permission from [Publisher].] 
NOT THE PUBLISHED VERSION; this is the author's final, peer-reviewed manuscript. The published version may be accessed by following the link in the citation at the bottom of the page.

Ganesh, S., \& Holmes, P. (2011). Positioning intercultural dialogue - theories, pragmatics, and an agenda. Journal of International and Intercultural Communication. 4 (2), 81-86.

Grasmuck, S., Martin, J., \& Shanyang, Z. (2009). Ethno-racial identity displays on Facebook. Journal of Computer-Mediated Communication, 15 (1), 158-188. doi:10.1111/j.1083-6101.2009.01498.x

Green, E., \& Singleton, C. (2007). Mobile selves: Gender, ethnicity and mobile phones in the everyday lives of young Pakistani-British women and men. Information, Communication \& Society, 10 (4), 506-526. doi:10.1080/13691180701560036

Guéguen, N. (2008). Helping on the web: Ethnic stereotypes and computermediated communication. Research Journal of Social Sciences, 3, 1-3.

Habermas, J. (1987). The theory of communicative action: Volume 2. Boston, MA: Beacon Press.

Hichang, C., \& Jae-Shin, L. (2008). Collaborative information seeking in intercultural computer-mediated communication groups: Testing the influence of social context using social network analysis. Communication Research, 35 (4), 548-573.

Hopkins, L. (2008). Muslim Turks and anti-Muslim discourse: The effects of media constructions of 'Islamic' and 'Arabic' in Australia. Australian Journal of Communication, 35 (1), 41-55.

Hu, S. L. Y., \& Leung, L. (2003). Effects of expectancy-value, attitudes, and use of the Internet on psychological empowerment experienced by Chinese women at the workplace. Telematics and Informatics, $20(4)$, $365-382$.

Jiali, Y. (2006). Traditional and online support networks in the cross-cultural adaptation of Chinese international students in the United States. Journal of Computer-Mediated Communication, 11 (3), 863-876. doi: $10.1111 / j .1083-6101.2006 .00039 . x$

Jones, S. (2001). Understanding micropolis and compunity. In Ess, C. (Ed.), Culture, technology, communication: Towards an intercultural global village (pp.53-66). Albany, NY: State University of New York Press.

Karlsson, L. (2006). The diary weblog and the travelling tales of diasporic tourists. Journal of Intercultural Studies, 27 (3), 299-312. doi: $10.1080 / 07256860600779303$

Katz, J. E., Aakhus, M. (Eds.). (2002). Perpetual contact: Mobile communication, private talk, public performance. Cambridge, UK: Cambridge University Press.

Khan, M. (1992). Communication patterns of sojourners in the process of acculturation. The Journal of Development Communication, 3, 65-73.

Kim, Y.Y. (1988). Communication and cross-cultural adaptation: An integrative theory. Philadelphia, PA: Multilingual Matters.

[Citation: Journal/Monograph Title, Vol. XX, No. X (yyyy): pg. XX-XX. DOI. This article is @ [Publisher's Name] and permission has been granted for this version to appear in e-Publications@Marquette. [Publisher] does not grant permission for this article to be further copied/distributed or hosted elsewhere without the express permission from [Publisher].] 
NOT THE PUBLISHED VERSION; this is the author's final, peer-reviewed manuscript. The published version may be

accessed by following the link in the citation at the bottom of the page.

Kim, Y.Y. (2001). Becoming intercultural: An integrative theory of communication and cross-cultural adaptation. Thousand Oaks, CA: Sage.

Koc, M. (2006). Cultural identity crisis in the age of globalization and technology. The Turkish Online Journal of Educational Technology, 5 (1), 37-43.

Lin, J., Peng, W., Kim, M., Kim, S., \& LaRose, R. (2012). Social networking and adjustments among international students. New Media \& Society, 14 (3), 421-440. doi: $10.1177 / 1461444811418627$

Ling, R. (2008). New tech, new ties: How mobile communication is reshaping social cohesion. Cambridge, MA: MIT Press.

Ma, Ringo (1996). Computer-mediated conversations as a new dimension of intercultural communication between East Asian and North American college students. In S. C. Herring (Ed.), Computer-mediated communication: Linguistic, social and cross-cultural perspectives (pp. 173-186). Amsterdam: John Benjamins Publishing Company.

Martinez, V. (2010). University training and education for interculturality in student mobility in Hong Kong. E-Proceedings of The International Online Language Conference (IOLC), 60-67.

McEwan, B., \& Sobre-Denton, M. (2011). Virtual cosmopolitanism: Constructing third cultures and transmitting social and cultural capital through social media. Journal of International and Intercultural Communication, 4 (4), 252-258.

Meagher, M.L., \& Castanos, F. (1996). Perceptions of American culture: The impact of an electronically mediated cultural exchange program on Mexican high school students. . In S.C. Herring (Ed.), Computermediated communication: Linguistic, social and cross-cultural perspectives (pp. 187-203). Amsterdam: John Benjamins Publishing Company.

Mehra, B., Merkel, C., \& Bishop, A. P. (2004). The Internet for empowerment of minority and marginalized users. New Media \& Society, 6 (6), 781 802.

Mollov, M., \& Schwartz, D. G. (2010). Towards an integrated strategy for intercultural dialog: Computer-mediated communication and face to face. Journal of Intercultural Communication Research, 39 (3), 207224. doi: $10.1080 / 17475759.2010 .534905$

Nakamura, L. (2009). Don't hate the player, hate the game: The racialization of labor in World of Warcraft. Critical Studies in Media Communication, 26 (2), 128-144. doi:10.1080/15295030902860252

Nelson, G., \& Temples, A. (2011). Identity construction as nexus of multimembership: Attempts at reconciliation through an online intercultural communication course. Journal of Language, Identity \& Education, 10 (2), 63-82. doi:10.1080/15348458.2011.563636

[Citation: Journal/Monograph Title, Vol. XX, No. X (yyyy): pg. XX-XX. DOI. This article is @ [Publisher's Name] and permission has been granted for this version to appear in e-Publications@ Marquette. [Publisher] does not grant permission for this article to be further copied/distributed or hosted elsewhere without the express permission from [Publisher].] 
NOT THE PUBLISHED VERSION; this is the author's final, peer-reviewed manuscript. The published version may be

accessed by following the link in the citation at the bottom of the page.

Oh, D. (2012). Mediating the boundaries: Second-generation Korean American adolescents' use of transnational Korean media as markers of social boundaries. International Communication Gazette, 74 (3), 258-276. doi: $10.1177 / 1748048511432607$

Pfeil, U., Zaphiris, P., \& Ang, S. C. (2006). Cultural differences in collaborative authoring of Wikipedia. Journal of Computer-Mediated Communication, 12 (1), 88-113. doi:10.1111/j.1083-6101.2006.00316.x

Pflug, J. (2011). Contextuality and computer-mediated communication: A cross cultural comparison. Computers in Human Behavior, 27 (1), 131137. doi: $10.1016 /$ j.chb.2009.10.008

Raman, P., \& Harwood, J. (2008). Acculturation of Asian Indian sojourners in America: Applications of the cultivation framework. Southern Communication Journal, 73, 295-311.

Richardson, R., \& Smith, S. W. (2007). The influence of high/low-context culture and power distance on choice of communication media: Students' media choice to communicate with professors in Japan and America. International Journal of Intercultural Relations, 31 (4), 479501. doi: $10.1016 / j$.ijintrel.2007.01.002

Schroeder, R. (2010). Mobile phones and the inexorable advance of multimodal connectedness. New Media \& Society, 12 (1), 75-90. doi: $10.1177 / 1461444809355114$

Shu-Chuan, C., \& Sejung Marina, C. (2011). Electronic word-of-mouth in social networking sites: A cross-cultural study of the United States and China. Journal of Global Marketing, 24 (3), 263-281. doi: $10.1080 / 08911762.2011 .59246$

Shuter, R. (2011). Introduction: New media across cultures-prospect and promise. Journal of International \& Intercultural Communication, 4 (4), 241-245. doi:10.1080/17513057.2011.598041

Shuter, R. (2012). When Indian women text message: Culture, identity, and emerging interpersonal norms of new media. In P. H. Cheong, J. $\mathrm{N}$. Martin, \& L. Macfadyen, L. (Eds.), New media and intercultural communication: Identity, community and politics (pp. 209-222). New York: Peter Lang.

Shuter, R., \& Chattopadhyay, S. (2010). Emerging interpersonal norms of text messaging in India and the United States. Journal of Intercultural Communication Research, 39 (2), 123-147. doi: $10.1080 / 17475759.2010 .526319$

Shuter, R., \& Chattopadhyay, S. (2012). Mobile phone activity and community: A cross-national study of socio-cultural values and the social uses of mobile phones. Paper presented at the National Communication Association, November, 2012.

Singh, C. (2010). New media and cultural identity. China Media Research, 6 (1), 86-90.

[Citation: Journal/Monograph Title, Vol. XX, No. X (yyyy): pg. XX-XX. DOI. This article is @ [Publisher's Name] and permission has been granted for this version to appear in e-Publications@Marquette. [Publisher] does not grant permission for this article to be further copied/distributed or hosted elsewhere without the express permission from [Publisher].] 
NOT THE PUBLISHED VERSION; this is the author's final, peer-reviewed manuscript. The published version may be

accessed by following the link in the citation at the bottom of the page.

Spurgeon, C., \& Goggin, G. (2007). Mobiles into media: Premium rate SMS and the adaptation of television to interactive communication cultures. Continuum: Journal of Media \& Cultural Studies, 21 (2), 317-329. doi: $10.1080 / 10304310701278173$

St.Amant, K. (2002). When cultures and computers collide: Rethinking computer-mediated communication according to international and intercultural communication expectations, Journal of Business and Technical Communication, 16, 196-214, doi: $10.1177 / 1050651902016002003$

Starosta, W.J., \& Olorunnisola, A. (1998). A meta model for third culture development. In G.M. Chen, \& W.J. Starosta (Eds.), Foundations in intercultural communication (pp. 45-63). Boston, MA: Allyn Bacon.

Steinkuehler, C. A., \& Williams, D. (2006). Where everybody knows your (screen) name: Online games as "third places". Journal of ComputerMediated Communication, 11 (4), 885-909. doi:10.1111/j.10836101.2006.00300.x

Tajfel, H., \& Turner, J.C. (1986). The social identity theory of intergroup behavior. In $\mathrm{H}$. Tajfel (Ed.), Social identity and intergroup relations (pp. 234-256). Cambridge: Cambridge University Press.

Tokunaga, R. S. (2009). High-speed internet access to the other: The influence of cultural orientations on self-disclosures in offline and online relationships. Journal of Intercultural Communication Research, 38 (3), 133-147. doi:10.1080/17475759.2009.505058

Turkle, S. (1995). Life on the screen: Identity in the age of the internet. New York: Simon \& Schuster.

Wang, C. (2012). Using facebook for cross-cultural collaboration: The experience of students from Taiwan. Educational Media International, 49 (1), 63-76.

Wang, Z., Walther, J. b., \& Hancock, J. T. (2009). Social identification and interpersonal communication in computer-mediated communication: What you do versus who you are in virtual groups. Human Communication Research, 35 (1), 59-85.

Ward, M. (2010). Avatars and sojourners: Explaining the acculturation of newcomers to multiplayer online games as cross-cultural adaptations. Journal of Intercultural Communication, 7 (23).

Wiseman, R., \& Koester, J. (Eds.). (1993). Intercultural communication competence. Thousand Oaks, CA: Sage Publications.

Würtz, E. (2005). Intercultural communication on web sites: A cross-cultural analysis of web sites from high-context cultures and low-context cultures. Journal of Computer-Mediated Communication, 11 (1), 274299. doi:10.1111/j.1083-6101.2006.tb00313.x

[Citation: Journal/Monograph Title, Vol. XX, No. X (yyyy): pg. XX-XX. DOI. This article is @ [Publisher's Name] and permission has been granted for this version to appear in e-Publications@Marquette. [Publisher] does not grant permission for this article to be further copied/distributed or hosted elsewhere without the express permission from [Publisher].] 
NOT THE PUBLISHED VERSION; this is the author's final, peer-reviewed manuscript. The published version may be accessed by following the link in the citation at the bottom of the page.

Ye, J. (2005). Acculturative stress and use of the Internet among East Asian international students in the U.S. CyberPsychology \& Behavior, 8, 154161.

Ying, Y., \& Liese, L. (1991). Initial adaptation of Taiwan foreign students in the US. International Journal of Intercultural Relations, 15 (33), 345366.

Yoon, R. (1996). Yin/yang principles and the relevance of externalism and paralogic rhetoric to intercultural communication. Journal of Business and Technical Communication, 11, 297-320.

Young-ok, Y., \& Hara, K. (2005). Computer-mediated relationship development: A cross-cultural comparison. Journal of ComputerMediated Communication, 11(1), 133-152. doi:10.1111/j.10836101.2006.tb00307.x 